UDC 75.071.1:929 Četirević J. 75(497.11)"17/18"

https://doi.org/10.18485/ms_zmslu.2021.49.4

Оригинални научни рад

Александра П. Кучековић*

\title{
ЕРМИНИЈА СЛИКАРА ЈОВАНА ЧЕТИРЕВИЋА ГРАБОВАНА - ЗАПИСИ И ЦРТЕЖИ
}

САЖЕТАК: Рукописна ерминија сликара Јована Четиревића Грабована, која се чува у библиотеци православне црквене оштине у Њиређхази у Мађарској, садржи, поред главног текста, низ других записа, текстова и цртежа које су отац и син, Јован и Никола Грабован, уносили све до средине треће деценије XIX столећа. У раду се анализирају порекло и садржај ове хетерогене групе текстова, која омогућава увид у распон њихових професионалних, интелектуалних, али и свакодневних практичних интересовања и потреба. Записи и цртежи у рукопису сведоче и о дивергентним утицајима и изворима знања којима су били изложени, првенствено у смислу контакта са садржајима западноевропских издања из области медицине, фармације, хемије/алхемије, па чак можда и географије и зоологије. Њихови примарни образовни и интелектуални оквири, које такође одсликава садржај рукописа, остали су обележени јужнобалканском традицијом и нововековном грчком ученошћу.

КљУЧНЕ РЕЧИ: Јован Четиревић Грабован, Никола Грабован, поствизантијски сликарски приручници (ерминије), записи српских сликара, цртежи српских сликара XVIII и XIX столећа, животиње у уметности, мајмун у уметности.

Рукописна ерминија која је припадала сликару Јовану Четиревићу Грабовану (Грабово, Албанија, око 1716. - Слатина, Хрватска, 1789) јединствен је сачувани и досад познати пример такве врсте документа о српској уметности XVIII столећа (MoutAFov 2002: 217-218; Тодит 2010: 357-377; КучекОвић 2020: 137-138). За разлику од његовог ранијег савременика и, вероватно, сународника јужнобалканског цинцарског порекла, сликара и графичара Христофора Жефаровића (МутАфов 2001: 150-181, 200-218), Јован Четиревић Грабован није био ни аутор ни састављач/преписивач ерминије на грчком језику. Он је, како је сам у њему забележио (MoUTAFOV 2002: 219; Тодић 2010: 356 , нап. 3), купио рукопис са текстом ерминије исписаним на првих 256 страница књиге (сл. 10). Предузета кодиколошка анализа откриће пуну садржинску структуру тог текста и поставити прецизније тезе о времену и могућем месту његовог

\footnotetext{
* Универзитет уметности у Београду, Факултет ликовних уметности, akucekovic@gmail.com
} 
настанка. Прелиминарни закључци указују на могућност да Грабованов рукопис спада у најобимније текстове ове врсте до сада откривене, вероватно светогорског порекла. ${ }^{1}$ У фокусу овог рада су делови рукописа који су настали касније од изворног текста ерминије и налазе се на преосталим страницама књиге (р. 275-352). По свему судећи, њих су написали двојица аутора: сликар Јован Четиревић Грабован и његов син, Никола Грабован (Осијек, 1772. - Осијек, 1824), који се вероватно такође бавио сликарством и, као и његов отац, био житељ Доњег града у Осијеку (KUС̌EKOVIĆ 2020: 140-143). Обојица су у рукопис уносили различите преписе и белешке, најкасније до 1789. када је реч о Јовану Четиревићу Грабовану и 1824. године, када је у Осијеку умро Никола Грабован. Међу текстовима које је исписао Јован Четиревић Грабован, научну пажњу најпре су привукле биографске белешке о њему и његовој породици, које је писао на грчком језику (MouTAFOV 2002: 218-225; Тодић 2010: 356-377), а потом су анализиране и црквенословенске белешке истог карактера које је исписао Никола Грабован (KUС̌EKOVIĆ 2020: 139-143).

Биографске забелешке оца и сина Грабована у рукописној ерминији су у досадашњим истраживањима сврстане у категорију приватне меморије, којом су аутори настојали да успоставе континуитет породичног памћења и сачувају од заборава егзистенцију појединца, ма колико кратка она била (Тимотијевић 2006: 263-275; Тодић 2010: 356). Тако су Јован и Никола Грабован сачували сећање не само на своје порекло, кроз уписивање датума рођења и смрти својих родитеља и ближњих, већ су у меморији ове врсте оставили место и за дирљиве помене на нестале потомке - децу која су рано умирала (ТодиЋ 2010: 373; KUС̌EKOVIĆ 2020: 142-143). Биографске белешке Грабована уклапају се у контекст бројних сличних сачуваних белешки на маргинама књига и рукописа из савремене приватне сфере, а њихова форма веома је слична записима у сачуваним тефтерима и ерминијама балканских зографа прве половине XIX столећа (Русева 2010: 9; cf. МутАфов 2001: 20). Разноликост других текстова који се појављују на страницама рукописа омогућава праћење ширих животних и професионалних интересовања Јована и Николе Грабована. У тренутку када је Никола уносио последње белешке, вероватно имајући рукопис у свом поседу све до смрти 1824, он је попримио облик мултифункционалне породичне сваштаре у коју су patres familias забележили важне датуме, практична знања која су обележавала посао и свакодневицу, као и сасвим посебне екскурсе у свет егзотичних животиња и алхемије. Значајан део текстова везан је за сликарску професију - и Јован и Никола су преписивали додатне делове из ерминија на грчком језику; текстови овог типа налазе се, највећим делом, на страницама које непосредно следе главни део рукописа. ${ }^{2}$ Приметно је да је Никола Грабован, изразито дистинктивним и китњастим рукописом у односу на старији очев рукопис, испуњавао странице које је Јован Четиревић Грабован остављао празне, накнадно преписујући тематски сродне одломке или остављајући референце на очеве записе.

${ }^{1}$ На информацијама о садржинској структури изворног грчког текста ерминије захваљујем колегама Контантиносу Јакумису из Тиране (Konstantinos Giakoumis, Tirana) и Константину Вафејадису из Атине (Constantine M. Vapheiades, Atina).

2 Група ових текстова налази се на страницама 257-274. 
Веома занимљиву групу текстова, који можда спадају у најраније у рукопису и чији је аутор Јован Четиревић Грабован, чине низови записа који се исписују на иконама и деловима иконостаса, преписи делова библијског текста, црквених химни и молитава. Сликар их је већином исписивао паралелно на грчком и црквенословенском, при чему су грчки записи исписани брзо, лако и сигурно, док су они на црквенословенском изведени знатно несигурније и са грешкама. Њиховом датовању у рани период делатности Јована Четиревића Грабована у Карловачкој митрополији, у време непосредно након 1769. и његовог преласка са породицом из родног Грабова у Нови Сад (Тодић 2010: 364-365; KUС̌екOVIĆ 2020: 140-141), доприноси и чињеница да је сликарев примарни професионални језик био грчки, којим се служио докраја живота. Наспрамни записи на грчком и црквенословенском језику на страницама 278-301, измешани са каснијим записима сродне садржине Николе Грабована, изгледају као практичне вежбе сликара који је нагло променио географску и језичку средину и убрзано се прилагођавао потребама своје нове српске клијентеле у Карловачкој митрополији. Странице су испуњене записима који се исписују на царским и бочним дверима иконостаса, на свицима које носе апостоли, пророци и други светитељи, при чему се местимично појављују и напомене о датумима њиховог прослављања. На страници 282 налазе се референце за текстове који се исписују на свицима светих песника Јована Дамаскина, Козме Мајумског и Теофана Песмописца. Њихове ликове Јован Четиревић Грабован је насликао на певницама Богородичине цркве у Ораховици 1775. (Кучековит 2004: 229, 235) (сл. 1), а поменути исписи у ерминији изгледају као припремне белешке за извођење записа управо на тим иконама. На страници 291 исписан је запис за икону Свете Тројице; први његов део појављује се на икони Светиа Тројица крунишу Боі̄ороgииу, сачуваној у православној Цркви Свете Тројице у Мишколцу. Икона је сликана на платну и налази се у каснијем неокласицистичком раму, али се, с обзиром на стилске карактеристике, може сматрати познијим радом Јована Четиревића Грабована, или неког од његових сарадника. ${ }^{4}$ У наставку једне од стра-

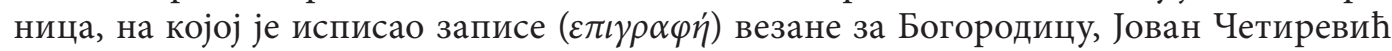
Грабован је забележио своје име на грчком, у форми ауторског записа (р. 323), какав је често остављао на својим раним радовима за грчко-цинцарску клијентелу - „ठь

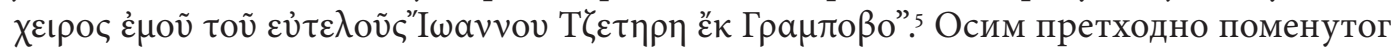
записа којим је убележио своје власништво над ерминијом, исписаног у секвенцама

з Записи и у рукопису и на поменутој икони у Мишколцу исписани су црквенословенским језиком: „О(т)цъ дщеръ С(и)мъ же М(а)теръ Д(8)хъ С(ве)тыи Нъвест8 вънчаютъ...”. Записи сличне садржине појављују се на иконама Крунисања Боіороgице на иконостасима Димитрија Бачевића у Николајевској цркви у Земуну (1762) и Стефана Тенецког у Вазнесењској цркви у Руми (1772) (ВукСАН 2016: 215).

4 У православној цркви у Мишколцу сачувана је још једна икона Крунисана Боїороgице коју је Јован Четиревић Грабован сликао и потписао на грчком 1773. (cf. Тодић 2013, књ. I: 288). Свечани запис

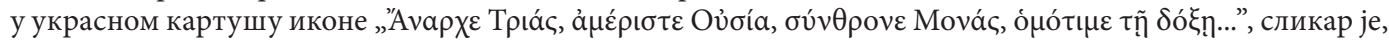
у варијацијама, исписивао и у рукопису ерминије.

5 „Руком мене недостојног Јована Тзетиири из Грампова.” Запис је транскрибовао и превео колега Константинос Јакумис, Тирана. 


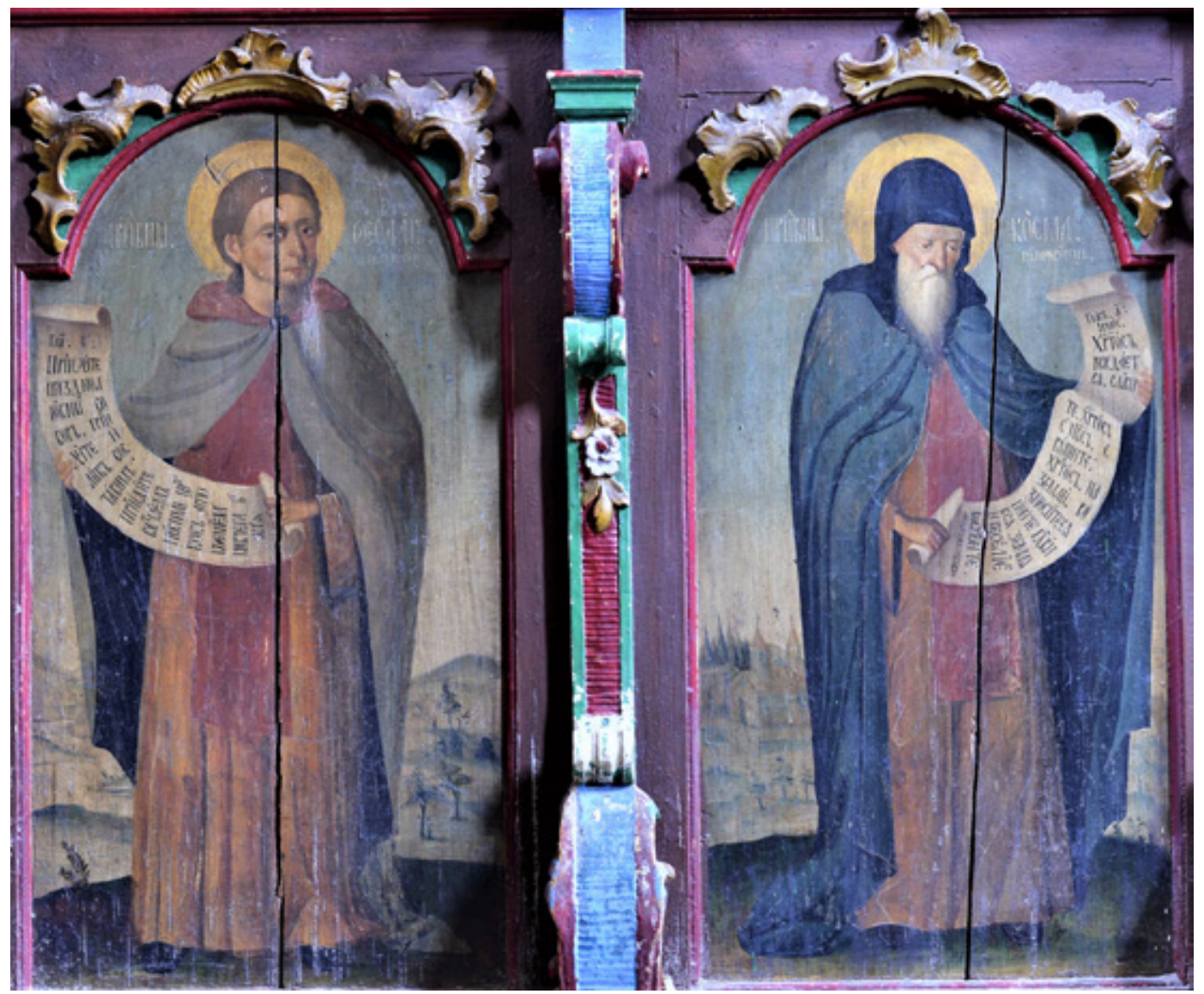

Сл. 1. Јован Четиревић Грабован, Светии Теофан Песмойисаи и Светии Козма Песмойвораи, иконе на певници Богородичине цркве у Ораховици (Хрватска), 1774/75.

(фото: МСПЦ, Београд)

од по неколико речи на првим страницама, Јован Четиревић Грабован је своје име исписао само још на овом месту у рукопису и то на једној страници, у континуитету са претходним записима истоветних карактеристика, што је значајно олакшало атрибуцију његовој руци других записа на грчком и црквенословенском, али и њихову дистинкцију у односу на рукопис Николе Грабована. ${ }^{6}$

У рукопису се појављују и други текстови који сведоче о сликарским, позлатарским и осталим уметничко-занатским интересовањима и активностима Грабована. На страницама 302-308, преписани су, на немачком језику, рецепти за препарацију

${ }^{6}$ Ауторство Николе Грабована одређено је такође на основу једног записа у којем он помиње себе у првом лицу и своју кћер (KUČEKOVIĆ 2020: 139-140). 
китова за различите намене (за порцелан, чаше, стакло итд.), преузети у целости из популарног сликарско-занатског приручника Praktisches Handbuch fur Kunstler, Lackierliebhaber und Oehlfarben-Anstreicher Немца Х. Ф. А. Штукла (Heinrich Friedrich August Stöckel), први пут објављеног у Нирнбергу 1799. године.7 Сви рецепти последњег поглавља књиге под насловом Verschiedene Kitte zu machen (STÖCKEL 1804: 270-274) пажљиво су преписани сигурним рукописом, готицом. ${ }^{8}$ Преписивач је, с обзиром на годину издања извора текста, од Грабована могао бити само Никола Грабован, који је иза првог преписаног рецепта за кит којим се лепи разбијена лула (cf. STÖCKEL 1804: 274), оставио додатне записе, црквенословенским и деломично латиницом. ${ }^{9}$ Све што се о Николи Грабовану као професионалцу поуздано зна своди се на податак да је 1807. за суму од 97 форинти у Богородичиној цркви у Доњем граду у Осијеку „фарбао” разне црквене предмете - полијелеје, крстове, путир (ГАвриловић 2009: 458; Тодић 2013, књ. II: 60). Текстови у рукопису ерминије, које је преписао, додатно осветљавају његову могућу каријеру, која није нужно морала бити каријера искључиво сликара иконописца. ${ }^{10}$ На црквенословенском је у рукопису очеве ерминије додатно исписао упутства за набавку „шпеција” које се користе приликом сечења слова на камену, за чишћење сребра, при справљању китова за мермер „кои се пребие илити разбие”, кита за „бели порцулан”, за „рознъ фарбъ”, итд. (рр. 308-309, 312, 318).

На страницама 324-337 су текстови исписани на латинском језику; да ли их је преписао Јован или Никола Грабован - није могуће с поузданошћу утврдити. Ипак, не постоје подаци да је Јован Четиревић Грабован функционално познавао латински језик. Извесна сигурност у препису текстова на овим страницама, као и друга овим рукописом посведочена интересовања Николе Грабована, чине управо њега вероватним преписивачем овог сегмента књиге, који је у целости посвећен хемији, односно алхемији. На почетку се налазе табеле са исписаним алхемијским алфабетом, симболима и њиховим нумеричким вредностима (Alphabetum chymicum et

7 Овде је кориштено допуњено и прерађено нирнбершко издање из 1804. године.

8 На помоћи у транскрипцији овог дела текста захваљујем колеги Ненаду Нинковићу из Новог Сада.

9 У рецептурама које је исписивао црквенословенским или грчким језиком Никола Грабован често је писао називе потребних састојака на немачком или латинском, латиничним писмом. Ипак, нема доказа да се активно служио немачким језиком, или знао да пише немачком готицом, тако да постоји немала вероватноћа да је од неког другог тражио да му препише потребне рецептуре за китове. Томе у прилог иде и подсећање које је исписао испод првог рецепта: „За ис...(?) луле коесу разбиене овое китъ”.

10 Л. Богдановић је, објављујући још 190о. први напис о Јовану Четиревићу Грабовану, у серији текстова у Срйском Сиону под називом „Срби сликари”, поменуо Николу и Константина Грабована као синове Јована Четиревића Грабована и житеље Осијека, напомињући да је „Константин такође био живописац, дочим за Николу нисам могао сазнати, на што се одао” (БогдАНОвИЋ 190о: 553). Константин Грабован је деловао као самостални сликар вероватно од очеве смрти 1789, па све до сопствене смрти 1804. (KUČEKOVIĆ 2020: 141-142, 150). Једино његово поуздано атрибуисано дело је уништени иконостас у православној цркви села Кобаш крај Славонског Брода из 1803. (Тодић 2013а: 276-302). Да ли се и Никола Грабован бавио сликањем икона и иконостаса и да ли је уопште практиковао сликарску професију ван Осијека, до данас није откривено. 


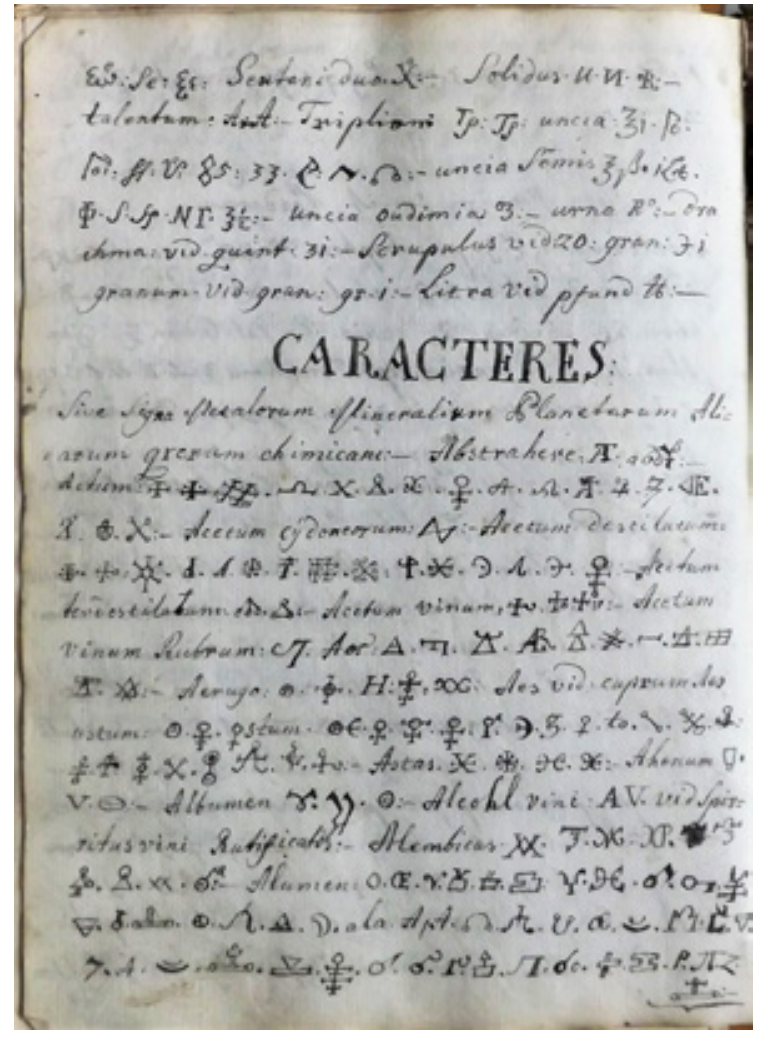

Сл. 2. Ерминија Јована Четиревића Грабована, страница текста са алхемијским појмовима и симболима (фото: А. Кучековић) numeruschi, Diphtongi chimici, Vocales chimici), потом су густо исписани текстови са стандардима различитих мера и тежина (Signa mensurarum et ponderum), симболима метала, минерала, планета и „других хемијских материја" (Caracteres sive signa metalorum, mineralium, planetarium, aliarum qrerum chimicam) (сл. 2), сложеним по абецедном реду. На посебној страници (р. 337) исцртана је табела са комбинацијама алхемијских симбола, при чему су делови текста исписани грчким језиком. Цео овај сегмент рукописа веран је препис додатка (сл. 3) штампаног на крају првог тома компендијума Nucleus totius Medicinae, немачког лекара, апотекара и писца Артура Конрада Ернстинга (Arthur Conrad Ernsting, 1709-1768) (HAARBECK 1953: 37-47), први пут штампаног у Хелмштату 1741. године. Овај свеобухватни лексиконски приручник савремених медицинских, хемијских и фармаколошких знања намењен, по речима његовог аутора, „савршеном и увек спремном апотекару, водећем хемичару и искусном лекару који пружа врхунску услу-

гу лечења", састоји се од пет делова, од којих први из 1741. представља фармаколошки лексикон и диспензаторијум. Ернстингови приручници чинили су део реформских настојања европске и немачке медицинске науке XVIII века ка инкорпорацији и модернизацији сложеног барокног наслеђа XVII столећа, које је укључивало традиционалну доктрину хуморалне патологије, без суштинског одступања од старог хипократско-галенског система. При томе су посебан проблем представљале систематизација и редукција збуњујућег и непрактичног мноштва фармаколошких препаратура које су укључивале и различите магијске продукте од измета, животињских састојака, лекова из „Новог света”, као и велики распон народних лекова. Алхемијска и херметичка искуства претходних векова остала су присутна у радовима немачких научника тог времена, о чему сведочи и Ернстингов лексикон (НABRICH 1991: 39-40).

Никола Грабован је био веома заинтересован за хемијске процедуре и процесе справљања сложених препаратура за различите намене; посебно је добро знао које 


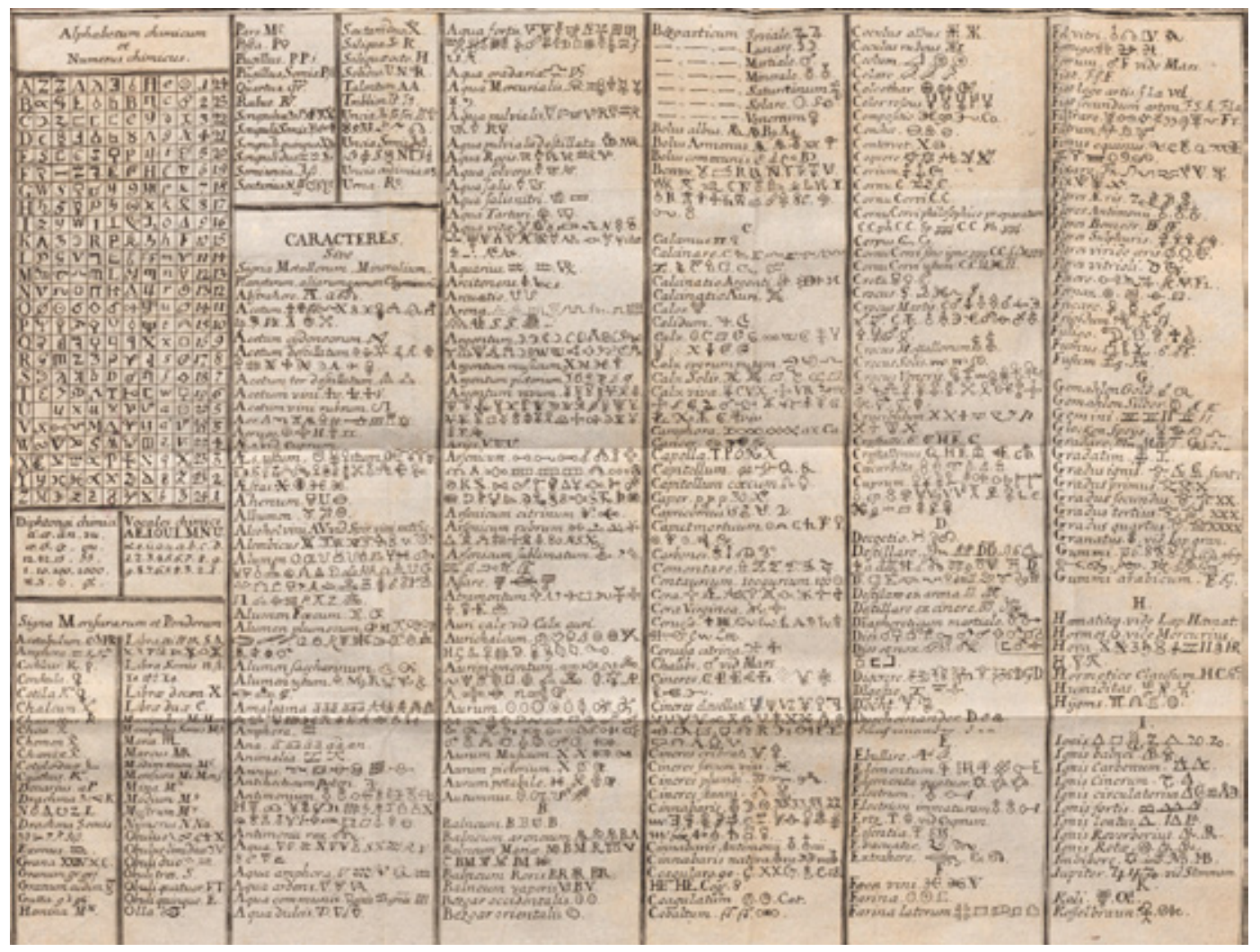

Сл. 3. А. К. Ернстинг, Nucleus totius medicinae, 1741. Додатак са табелама хемијских/ алхемијских појмова и симбола.

материје се могу набавити у апотеци. ${ }^{11}$ Рукопис ерминије његовог оца пун је доказа о Николиним интересовањима ове врсте, која укључују и рецептуре за справљање разних лекова. На страницама 302 и 311-319 формирао је праву малу приручну лекарушу, преписујући двадесетак рецепата за лечење различитих болести, вероватно оних које су најчешће погађале његову породицу. Међу њима су два лека за саниије (јаке болове у абдомену), као и лек за мицину - специфично упално обољење лимфних жлезда

${ }^{11}$ При навођењу састојака у рецептурама Никола Грабован прецизно одређује које се материје могу купити „готове” у апотеци, при чему неке од њихових назива исписује на немачком или латинском језику: „вода Salpeter Saure” (нем. Salpetersäure), „Gumi Arabicum” (нем. Gummi arabicum), „Lorber Öell”, док остале наводи у преводу „на србски“: „мастикс”, „ганцъ терпентинъ”, „калафони” (лат. Colophonium), „босилъ фластер” итд. У време када су вероватно настали ови записи Николе Грабована, у Осијеку је постојала пољска апотека (Feld Apotheke) у Тврђи, војном делу града. Након проглашења Осијека слободним краљевским градом 1809, у Горњем граду је 1812. основана још једна апотека, а тек после 1816. и у Доњем граду, где су живели Грабовани (FIRINGER 1953: 240-248). 
(cf. БЈелАковић 2003: 12-23). Никола Грабован преписао је и лекове за мање опасне, свакодневније бољке: шуљеве, главобољу, кашаљ, покварен стомак, зубобољу, лишајеве на кожи, болна крста и различите ране. Посебно су интересантни лекови које је свака оновремена породица вероватно веома ценила, а тицали су се неге мале деце - упутства за ефикасан третман (лаписирање) гранулома пупка новорођенчади, за лечење грчева и глиста код деце, али и дечјег акутног фебрилног стања којег се Никола Грабован, изгледа, највише прибојавао - „Од фраса Б(о)же сач8ваи”. Морталитет деце у Славонији у XVIII и првој половини XIX столећа био је изузетно висок, а општа здравствена заштита и култура веома лошег квалитета (GLESINGER 1955: 188-216; cf. ЈЕРЕмиЋ 1940: 268-286). У варошким срединама, попут Доњег града у Осијеку, настањеног великим бројем православаца, у породицама занатлија и трговаца деца су представљала залог просперитета и будућности и њиховом здрављу и бољем преживљавању прогресивно се придавао све већи значај (cf. Тимотијевић 2006: 401-404). Болест и смрт детета у породици Грабована имала је посебно место у колективном породичном искуству; белешке Јована Четиревића Грабована о смртима Николине браће који су помрли као деца (Тодић 2010: 364, 373), као и Николина настојања да стекне знања како да заштити сопствено потомство (cf. KUČEKOVIĆ 2020: 143), дирљива су и ретка сведочанства емоционалних преокупација унутар једне православне породице у провинцији Монархије крајем XVIII и почетком XIX века.

Карактер рецепата за лекове које је преписивао Никола Грабован у потпуности одговара традицији незваничне и несанкционисане народне медицине чија су се знања и искуства вековима преносили кроз популарне рукописне збирке препаратуpa, лекаруше (MEDIĆ 1909: 168-124). Оне су биле још увек веома цењени приручници за самолечење у XVIII столећу на подручју Славоније и Хрватске, иако је централна власт све више настојала да боље организује институције здравствене заштите и потисне ослањање на различите магијске праксе и сујеверице које су пратиле медицинску непросвећеност становништва (ROMANO 1973: 141-204; BELICZA 1991: 294-295, 299-300). Никола Грабован је своје рецепте преписао из неке лекаруше која је укључивала дуговечна искуства чувене средњовековне Салернске медицинске школе, комбиноване са традицијом народних лекова (GLESINGER 1955: 186-188). ${ }^{12}$ О томе сведочи и форма текстова тих рецепата, које Никола Грабован завршава честим афирмативним узречицама које су пратиле рецепте „проверених” лекова (medicinae aprobatae) у традиционалним лекарушама - „Пробирато је”, „И то лек буде” или једноставно: „Добро буде!” (Medić 1909: 170-178; Glesinger 1955: 35-36; БЈЕЛАКОвић 2003: 13). Као

12 Многе лекаруше са подручја Славоније, рукописне или штампане, потичу из XVIII столећа. У Осијеку је 1794. и 1796. штампана једна комбинована лекаруша, хумана и ветеринарска, аутора свештеника Јосипа Стјепана Рељковића, у којој су здравствена упутства за људе преузета из правила Салернске медицине. Јовану Четиревићу Грабовану, иако он није аутор преписа рецепата за лекове у рукопису, могла је бити позната и тзв. Лепавинска лекаруша, коју је у другој половини XVIII века саставио јеромонах Стефан Витановић (RoMANO 1973: 172, 174-175). 
и код препаратура за сликарске и занатске послове које је обављао, Никола Грабован се и приликом справљања лекова ослањао на фармаколошке супстанце које су биле доступне у апотекама. Ипак, подједнако је веровао и у делотворност лекова који су подразумевали за то доба већ сасвим неконвенционалну непосредну употребу делова животиња, магијске поступке и бајања. ${ }^{13}$

О статусу и употреби рукописа ерминије у породици Грабована може посредно посведочити и чињеница да се у њој налази веома мали број цртежа. Познато је да је ученик Јована Четиревића Грабована - Григорије Поповић, такође поседовао свеску у коју је уписивао биографске записе, али је у њој оставио и бројне цртеже и припремне скице за религиозне композиције и детаље (KUČEKOVIĆ 2020: 143-144, 147150). ${ }^{14}$ У Грабовановој ерминији постоје само два цртежа животиња и две скице декоративних барокних волута за тронове Христа или Богородице, које је често сликао на престоним иконама. И поред мноштва записа за свитке појединачних светитеља, варијанти записа на појединим елементима иконостаса и других преписа који су служили као предлошци за исписивање текстова на иконама, ни Јован ни Никола Грабован их нису попратили скицама у овом рукопису. Један од могућих разлога треба тражити и у чињеници да је примарни предложак за сликарство Јовану Четиревићу Грабовану била илустрована Biblia Ectypa аугзбуршког гравера Кристофа Вајгла - његов лични примерак са записима сачуван је до данас (Тодит 2010: 357). Све Вајглове графичке илустрације у Грабовановом примерку попраћене су записима на грчком, који представљају преводе библијских текстова одштампаних на латинском и немачком језику. ${ }^{15}$ Изгледа да су традиционална сликарска ерминија са додатним текстовима и корисним записима и Вајглова графичка збирка, у пракси Јована Четиревића Грабована, служиле као комплементи које је користио једновремено, у својеврсном сликарском унакрсном реферисању, које му је омогућавало да својим радовима подари популарни западњачки барокни визуелни идентитет и остане, притом, сасвим у оквирима ортодоксне садржајне коректности, коју је преферирала његова конзервативна провинцијска клијентела.

${ }^{13}$ Као лек за опасну болест - мицину, преписао је рецепт који је укључивао суделовање тројице мушкарца са хендикепима - глувог, хромог и слепог, и једну стару кост, која је била закопана у земљи, као средство бајања; код дечјег фраса рецепт за лек препоручује справљање тинктуре од праха спаљеног срца живе или мртве кртице.

${ }_{14}$ Свеска Григорија Поповића сведочила је о различитим визуелним изворима с којима је долазио у контакт и одакле је прецртавао фигуре и композиције - од грчких богослужбених штампаних књига са графичким илустрацијама, до предложака по којима је израдио скице Херкула Фарнезе, те Аполона и Хермеса Белведере из Ватикана. Цртежи су укључивали и скицу проласка комете 1769, као и скице пејзажа. Фигуре пророка, светитељки, апостола у ентеријеру, скице за извођење престоних икона Богородице, Христа, композиције Деизиса, анђела у лету, Христа у путиру и Свете Тројице на облацима представљају стандардизоване студије за извођење религиозних представа, које је савладавао под Грабовановим туторством (SĂNDULESCU-VERNA 1992: 123-126; CIOBANU 2019: 101-103; cf. KUČEKOVIĆ 2020: 143 , ref. 48).

${ }_{15}$ Ово би могло бити још један посредан доказ да се Јован Четиревић Грабован није служио ни латинским ни немачким језиком. 


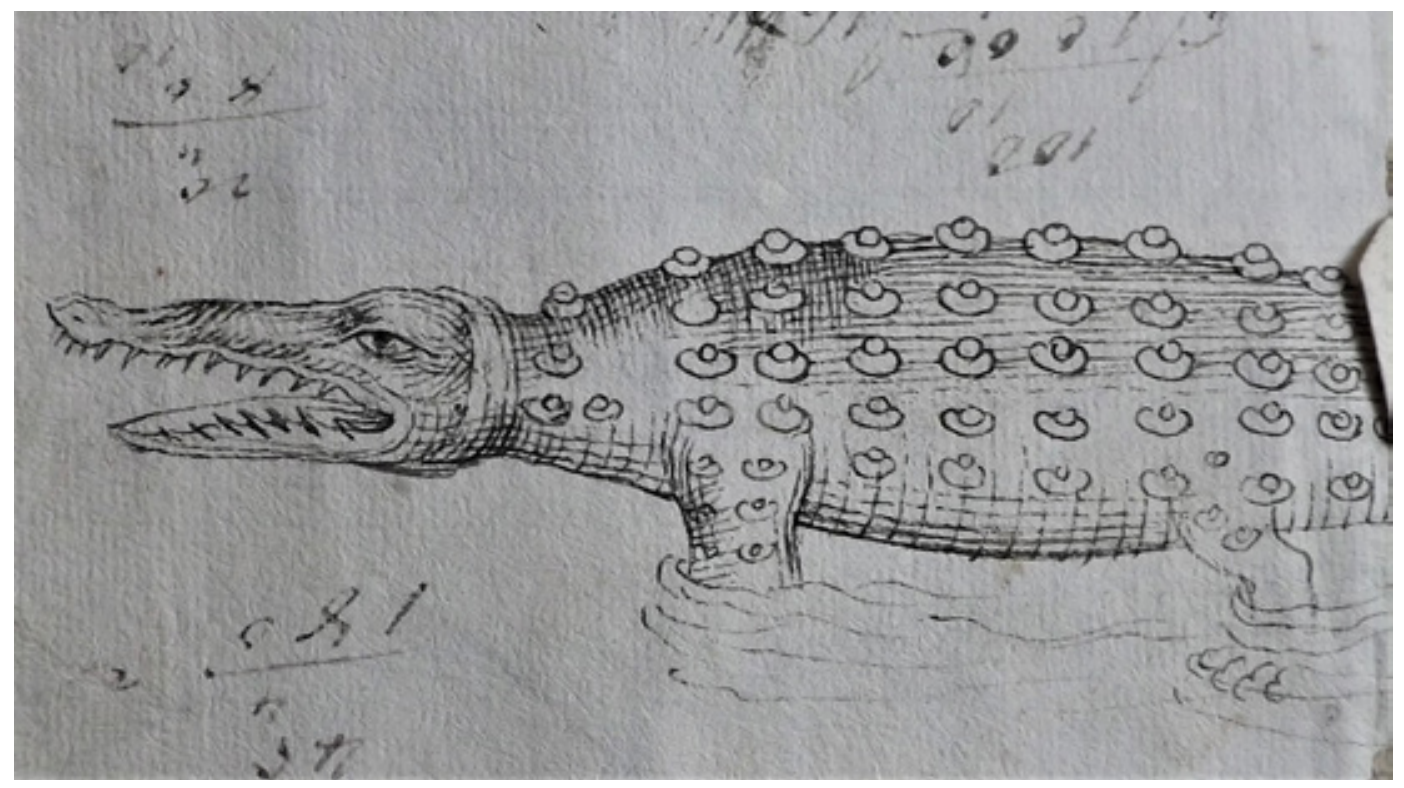

Сл. 4. Ерминија Јована Четиревића Грабована, цртеж крокодила (фото: А. Кучековић)

Два цртежа животиња у рукопису ерминије сведоче, међутим, о сасвим другачијим личним интересовањима, а њихова контекстуализација тек је делимичан увид у распон интелектуалних преокупација сликара Грабована. Оба се налазе на самом крају рукописа, на страницама које је Јован Четиревић Грабован користио за биографске записе и забелешке. Цртеж крокодила који стоји у води изведен је пером и црном тинтом на последњем листу у књизи (сл. 4), испод записа на грчком језику о смрти сликареве мајке Калије у Осијеку 1775. (MOUTAFOV 2002: 219-220) и вероватно га је он начинио. Детаљи цртежа, поготово рожнате коже и леђних израслина на животињи, као и донекле наивно третираних отворених чељусти са наглашеним оштрим зубима, сведоче о сликаревој фасцинацији створењем које сигурно никада уживо није видео, али које је побуђивало машту, како његову тако и оних којима је цртеж показивао. Цртеж није попраћен никаквим писаним коментарима, тако да је о његовом специфичнијем значењу у сликаревој имагинацији, као и о могућим разлозима његове недовршености, тешко закључивати, јер је фигура рептила приказана скраћена, без репа. Слика крокодила и прича о „крокодилским сузама”, као метафоре лицемерја, у средњовековној бестијарној симболици и нововековној амблематици имају веома дугу традицију, све до физиогномских студија Каспара Давида Лаватера, који је крокодилске карактеристике сматрао оличењем зла и ђаволске природе (МАхов 2015: 56-59). Цртеж би, међутим, могао представљати тек визуелну белешку куриозитета који је сликар уочио листајући неки од нововековних зоолошких компендијума (cf. ENENKEL 2007: 15-74), попут Historiae naturalis de Quadrupedibus, пољског лекара и научника 


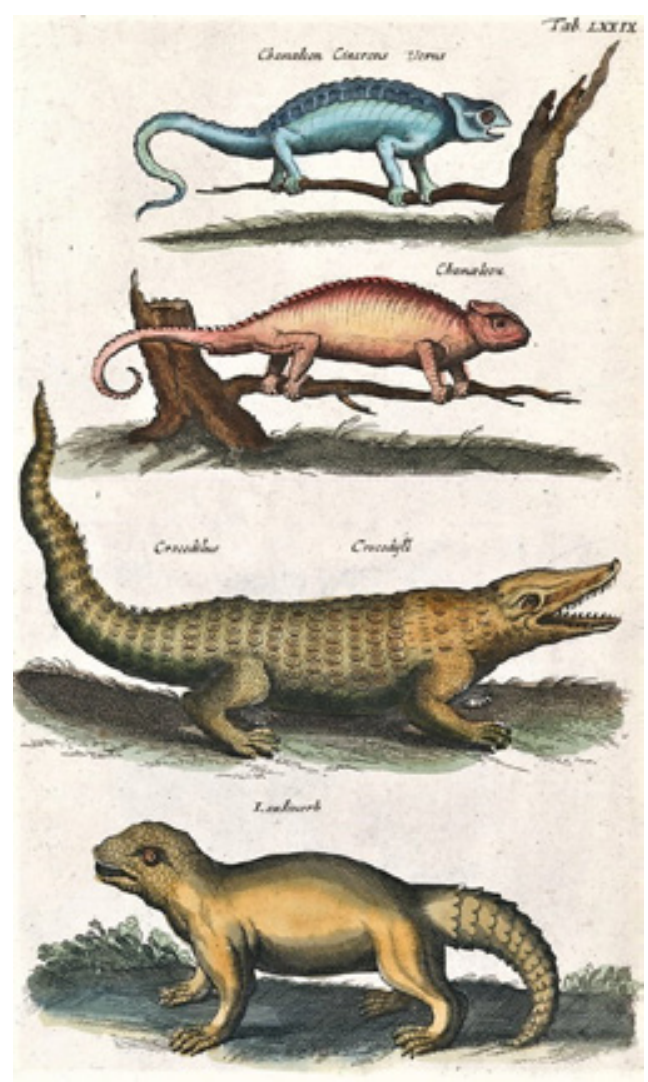

Сл. 5. Ј. Јонстон, Historiae naturalis de Quadrupedibus, 1657. Графичка илустрација са крокодилом и другим рептилима шкотског порекла Јана Јонстона (Johannes Jonstonus, 1603-1675), објављеног први пут у Амстердаму 1657. године. Илустрација нилског крокодила у Јонстоновој књизи (сл. 5), коју је извео швајцарски гравер Матеус Меријан (Matthäus Merian, 1621-1687) (JonstoNUS 1657: 141; cf. SPENNEMANN 2019: 201-239, 2019а: 2-9, 13-19, 26-35), веома је слична цртежу који је у својој ерминији оставио Јован Четиревић Грабован.

Неколико страница раније у рукопису, на листу који претходи корпусу биографских записа Јована Четиревића Грабована (р. 340), налази се целостранични цртеж човеколиког мајмуна који седи, затворених очију, испод дрвета смокве, са назначеним елементима брдовитог пејзажа у позадини (сл. 6). Цртеж је изведен танким пером и црном тинтом и дорађен сенчењем четкицом на телу и глави животиње. Аутора цртежа теже је одредити; сачувана сликана оставштина Јована Четиревића Грабована не сведочи о његовом познавању ни употреби сенчења у циљу остваривања пластичности фигура. Ипак, софистициран цртеж нагнутог дрвета иза фигуре мајмуна и диспозиција назначене позадине са брдима у другом плану веома подсећају на фине пејзажне пасаже које је Јован Четиревић Грабован остваривао на својим иконама - као пример могу послужити префињене висте у гризају на престоним иконама иконостаса у Моловину (1772) (сл. 11), или на престоној икони Светог Јована Крститеља и иконама црквених песника на певницама Богородичине цркве у Ораховици (1774-1775). О Николи Грабовану као могућем аутору овог цртежа може се само нагађати без чврстог основа, с обзиром на то да ниједно његово сликарско дело није познато; ${ }^{16}$ могућност да је овај цртеж у целости извео неко трећи такође није искључена. ${ }^{17}$

${ }^{16}$ На другој страни листа на којем се налази цртеж са мајмуном, Никола Грабован је оставио запис на грчком и црквенословенском о смрти своје сестре Анке (Анчице) Грабованове (KUČEKOVIĆ 2020: 143)

17 Овде би се могла поставити претпоставка о могућем ауторству Николиног брата, сликара Константина Грабована. Он се у рукопису помиње само у очевим и братовим записима о његовом рођењу 


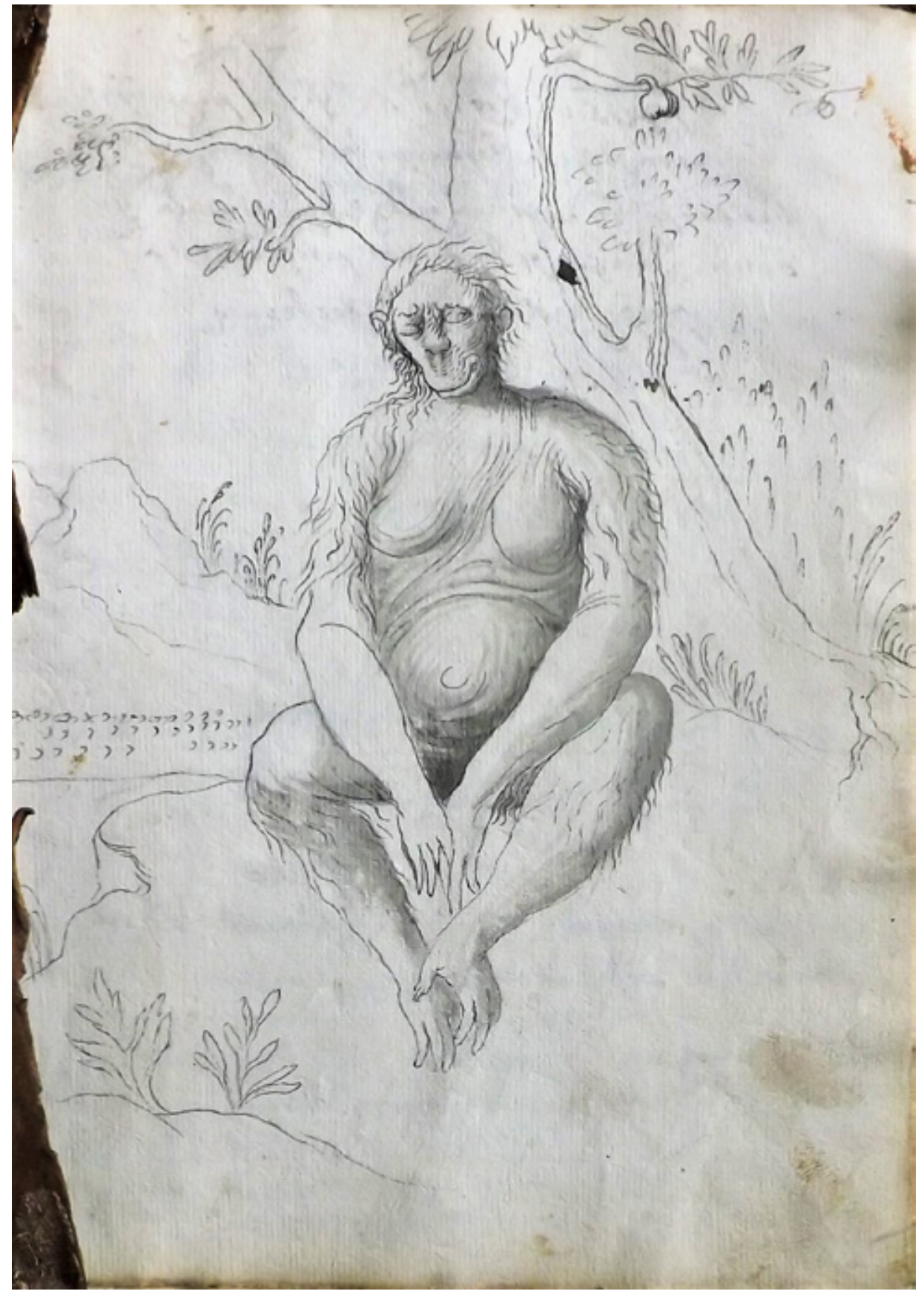

Сл. 6. Ерминија Јована Четиревића Грабована, цртеж човеколиког мајмуна (фото: А. Кучековић) 
Порекло предлошка за настанак овог цртежа може се, међутим, сасвим прецизно утврдити. Графичка илустрација под називом Homo sylvestris. Orang-outang први пут се појавила у књизи Observationum medicarum libri tres коју је 1641. у Амстердаму објавио холандски хирург Николас Тулп (Nicolaes Tulp, 1593-1647) (TUlP 1641: 275, таб. XIIII) (сл. 7). Тулпова збирка медицинских опсервација, популарно названа „Књигом о чудовиштима”, садржи, између осталог, и описе дисекције егзотичних животиња допреманих бродовима холандске Источноиндијске компаније; човеколики мајмун који је приказан у ствари је била афричка шимпанза из Анголе, а илустрација у Тулповој књизи сматра се најранијим сачуваним „научним” приказом ове животиње у Западној Европи. Сусрети Европљана са великим човеколиким мајмунима Азије или подсахарске Африке до Тулповог времена били су веома ретки и о њима нису постојала никаква систематска знања, ван митолошке матрице о „дивљим шумским људима”, при чему су велики мајмуни често стављани у исту групу егзотичних бића као и Пигмеји или Хо-

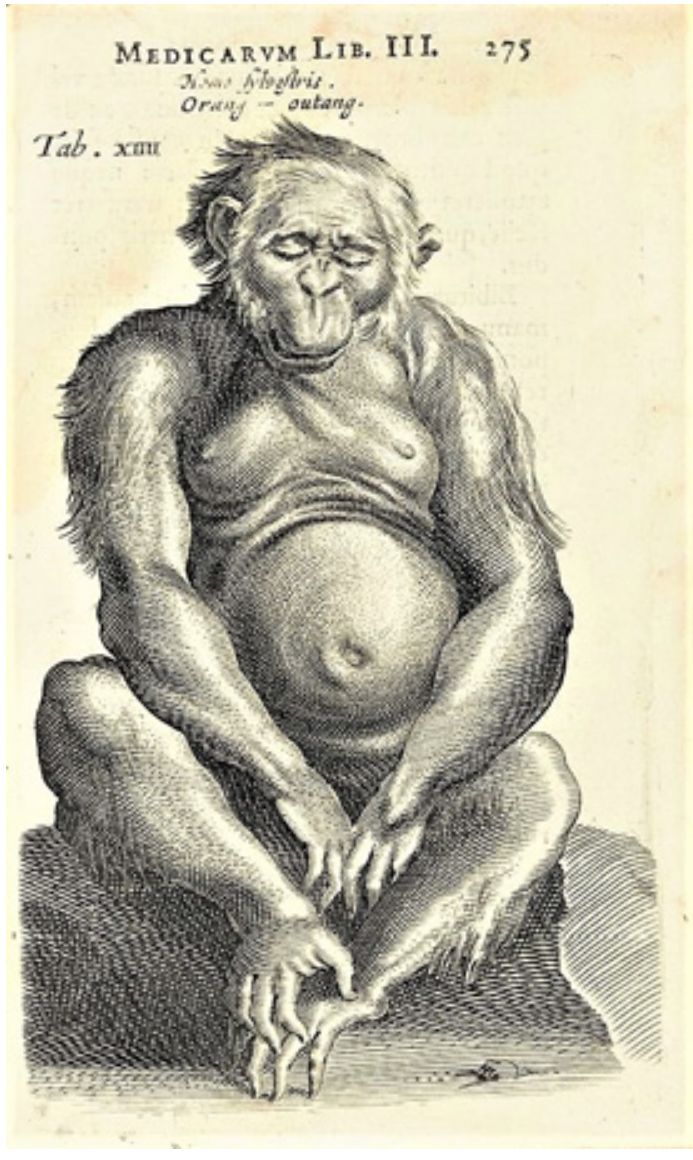

Сл. 7. Н. Тулп, Observationum medicarum libri tres, 1641. Homo Sylvestris. Orang-outang тентоти југозападне Африке (JANSON 1976: 332-333; cf. Sebastiani 2015-16: 109; cf. NieKERK 2004: 484). Занимање за човеколике мајмуне, покренуто истраживањима попут Тулповог, отворило је велико питање њихове „сличности” и разлике у односу на човека као Божју креацију; значајан напредак у научно заснованим опсервацијама човеколиких мајмуна остварен је развојем компаративне анатомије током XVII и XVIII столећа и успостављањем научно-филозофског дискурса о пореклу човека (STOCZKOWSKI 1995: 141-155; NIEKERK 2004: 479-481, 486-498; SEBASTIANI 2015-16: 105114). Пиониром компаративних анатомских студија човека и мајмуна у модерном смислу сматра се енглески научник и лекар Едвард Тајсон (Edvard Tyson, 1651-1708),

и смрти (сf. нап. 11); нема, међутим, доказа да се Константин служио очевом ерминијом, као ни да је у њој нешто цртао и/или записивао. 


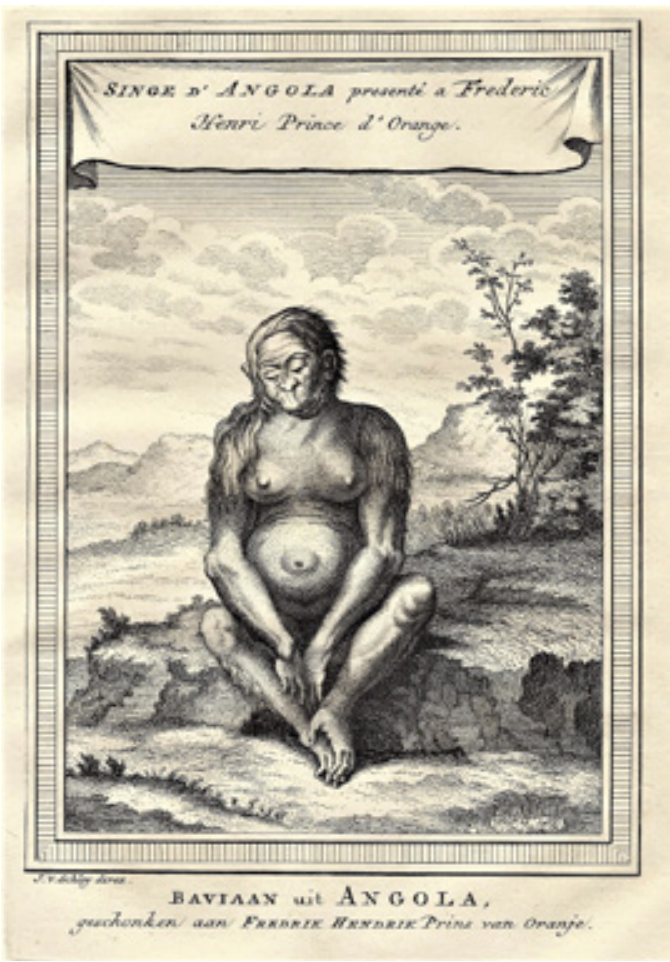

Сл. 8. А. Ф. Превост, Histoire generale des voyages..., шести том, 1748. Singe d'Angola, présenté à Frèdéric Henry, Prince d'Orange

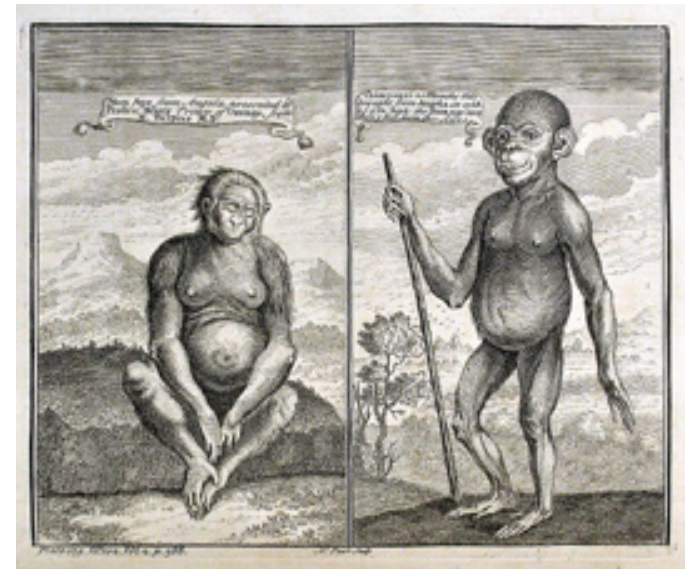

Сл. 9. Џ. Салмон, The Universal Traveller..., 1759. Man Ape from Angola, Presented to Frederick Henry, Prince of Orange, from N. Tulpius M.D. у чијем је класичном делу из 1699. Orang-Outang, sive Homo Sylvestris: or the Anatomy of a Pygmie Compared with that of a Monkey, an Ape and a Man, поновљена илустрација човеколиког мајмуна из Тулпове књиге (TYSON 1698: 106-107, fig. 15; cf. JANSON 1976: 335-338; cf. NIEKERK 2004: 480- 483; WILLIAMS 2008: 3-11). Касније, током XVIII века, појављују се и друге графичке илустрације које приказују Тулповог мајмуна, али адаптиране за потребе публикација немедицинског карактера. Веома занимљив пример је варијанта коју је холандски графичар Јакоб ван дер Шлеј (Jacob van der Schley, 1715-1799) израдио за шести том географско-историјског, антрополошког и путописног трактата Historie generale des voyages, објављиваног од 1746. до 1759. (PrÉvosT 1748: 410-411) (сл. 8). Шлејева графика приказује седећу животињу у пејзажу, са очигледним наглашавањем њених „женских” атрибута - груди, стомака, па чак и дужег прамена „косе” која пада преко десног рамена. Варијанта ове илустрације (сл. 9) појављује се и у другом тому путописа The Universal Traveller енглеског историчара и географа Џорџа Салмона (George Salmon, 1679-1767), објављеног у Лондону 1759. (SAlmon 1759: 388, pl. 179).

Судећи по карактеристикама цртежа у Грабовановој ерминији, његов аутор је вероватно имао прилике да види неку графичку илустрацију из XVIII столећа, засновану на Шлејевој обради приказа човеколиког мајмуна у књизи Николаса Тулпа. Пејзажна позадина на цртежу томе посебно говори у прилог, као и, како се чини, схватање приказане животиње као женске јединке. У том смислу, пажњу привлачи посебан акценат који не постоји на претходно наведеним графичким 
примерима - сасвим натуралистички приказан, усамљени плод смокве на грани. При томе је дрво које га носи третирано крајње генерализовано, без покушаја подражавања типичних карактеристика листова смокве, које су Јовану Четиревићу Грабовану, с обзиром на његово јужнобалканско порекло, могле бити познате. Колико је убацивање овог специфичног детаља, бременитог иконолошким потенцијалом, оригинална интервенција аутора, или представља ослањање на неки ранији извор, за сада остаје непознато, али тумачење значења читаве компилације скреће у правцу другачијем од контекста у ком је настао и касније адаптиран изворни графички предложак.

Смоква и њени плодови у хришћанској традицији били су мултифункционални и амбивалентни симболи, најчешће повезани са идејама Дрвета познања добра и зла, Богородице као нове Еве, али и телесне пожуде, еденског искушења и првородног rрехa (Moldenke 1952: 103-106; LeVi D'ANCONA 1972: 135-141). Средњовековна рецепција, утемељена на тексту Физиолоїа, дрво смокве је тумачила као метафору духовног просветљења за оне који су спознали Божји свет, попут инсеката који живе у плоду смокве, у тами, несвесни светлости спољног света која им се открива тек када се смоква отвори (CURLEY 2009: 41). Мајмуна, међутим, овај чувени текст сматра ликом самог ђавола који „има почетак, али нема крај”, односно реп, и коме потпуно недостаје лепота (CURLEY 2009: 39). У источнохришћанској сфери ликовне представе мајмуна релативно су ретке и повезане су са идејом демонског; у контексту антитезе анђеоског и демонског протумачене су и фреске са ликовима анђела и мајмуна на капителима поткуполних стубова у Марковом манастиру, насликаних 1376/1377. године. Њихова појава повезана је са могућим утицајем сличних симболичких концепата на вајаним капителима готичких и романичких цркава (Мирковић 1974: 253-254, 257-258; Томић-Ђурит 2019: 105-109). На Западу, романички период понешто је изменио строгу негативну симболику мајмуна наслеђену из ранохришћанског и раносредњовековног имагинаријума; мајмун, уместо директне персонификације ђавола, постаје репрезентација исквареног човека (hominum deformis imago) који је подлегао искушењима грешног тела. Similitudo hominis као одлика мајмуна, која се у теолошким разматрањима појављује у средњем веку, покренула је компарирање човека и мајмуна и схватање потоњег као симбола негативних људских особина, попут пожуде (lussuria), расипништва и среброљубља (JANSON 1976: 16-29, 73-99; COHEN 2008: 218-219). Веза мајмуна са првородним грехом и Адамом и Евом такође је успостављена у средњем веку и то, како се чини, пре у визуелним уметностима него у текстовима теолога. У представама везаним за егзистенцију прародитеља у рају пре пада на којима се појављује фигура мајмуна, она се често може протумачити као симбол Евиног карактера, који су теолози увек тумачили инфериорним у односу на Адамов, иако је он сматран првим грешником, у смислу потоњег усуда човечанства. Мајмун је готово увек повезиван са женским квалитетима - означаван је најчешће у женском роду на латинском језику (simia), а разне приче о превртљивости, нестабилном темпераменту и сензуалности мајмуна, па и чувена прича о мајмуници која у силној, али разумом 


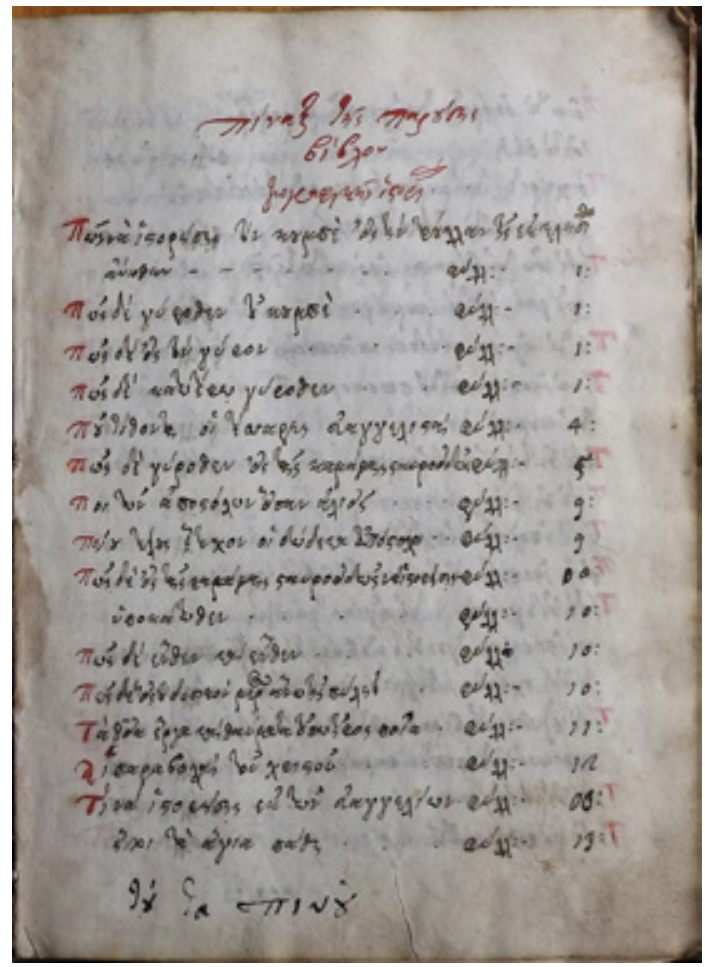

Сл. 10. Ерминија Јована Четиревића Грабована, прва страна садржаја рукописа

неконтролисаној љубави, удави своје младунче - све то допринело је фиксирању идеје о женском карактеру мајмуна у популарној имагинацији (JANSON 1976: 107136).

Чини се да у асоцијативном концепту који је произашао из претходно укратко изложене традиције треба тражити оквире за тумачење цртежа са мајмуном у Грабовановој ерминији. Упадљиво наглашен плод смокве изнад седеће животиње имплицира близину и привлачну снагу искушења и предстојећег греха. Мајмун као демон-ђаво, грешник или женска карнална и сензуална антитеза мушкој снази ума и вере - све би ово могли бити елементи рашчитавања идејног подтекста цртежа. Његов аутор му је поклонио посебну пажњу у извођењу, а у целини рукописа његово проминентно место је неспорно. Можда није случајно што страници са цртежом претходи страница на којој је рукописом Јована Четиревића Грабована исписан текст на грчком језику који говори о иконографији девет анђеоских чинова (р. 339). ${ }^{18}$ На крају последњег реда текста сликар је додао малу скицу клечеће фигуре и херувимских крила. Колико су овај текст и цртеж мајмуна са смоквом на следећој страни идејно повезани и да ли је могуће спекулисати о познавању литургијски заснованог контекста антитетичког повезивања ликова анђела и ђавола/ мајмуна, присутног у византијском сликарству на примеру из Марковог манастира, тешко је одредити, јер аутор цртежа у ерминији, као што је напоменуто, није уз њега оставио никакав писани коментар. Поствизантијска ликовна традиција позната Јовану Четиревићу Грабовану, али ни српско барокно религиозно сликарство XVIII столећа, не пружа значајнији ослонац за контекстуализацију цртежа у ерминији. Сликари савременици Јована Четиревића Грабована и његовог сина на подручју Охридске архиепископије и Карловачке митрополије - природу (пејзаж) су, у оквирима источнохришћанске традиције, схватали као слику раја, док су животиње сматране инхерентно злим и сликане су само када је то експлицитно налагао представљени библијски наратив (Тимотијевић 1993: 251; cf. MAGUIRE 2012: 166-173).

${ }_{18}$ На преводу овог дела текста са грчког језика захваљујем колеги Константиносу Јакумису из Тиране. 
Симболички потенцијали цртежа мајмуна у Грабовановој ерминији могу стајати у вези и са још једном популарном нововековном литерарном и ликовном метафором. Мајмун је у ренесансним трактатима о уметности интерпретиран као слика уметника-имитатора који, на исти другоразредни и неспретан начин као што мајмун имитира човека, подражава савршенство природе. Корени доктрине ars simia naturae формирају се у списима раних хришћанских теолога, попут Светог Августина Хипонског који, у неоплатонистичком духу, сматра да је уметност вредна само када се не такмичи са природом као одразом духа Творца, док је Климент Александријски, иступајући против идолатрије, оне који држе слике и статуе сматрао „нижим од мајмуна”. Рана ренесанса доноси концепт уметника који се све наглашеније труди да подражава природу, као некога ко тиме усваја одлике мајмуна имитатора и илузионисте. Ипак, у складу са процесом елевације уметности ка статусу либералне вештине, ове особине добијају позитиван карактер, претварајући уметника у прегаоца који, попут доброг хришћанина који се свим силама труди да имитира савршенство Бога, настоји да се што више приближи недостижном идеалу природе. У XVI и XVII столећу фраза ars simia naturae добија своје визуелне изразе на илустрацијама трактата о уметности и иконологији (JANSON 1976: 287-302, 73-99; COHEN 2017: 217-228). У Рипиној Иконолоіији из 1599, међутим, мајмун више није повезан директно са уметношћу, већ са женском персонификацијом која представља доктрину Imitatione, као неутралну карактеристику уметничког поступка (JANSON 1976: 304; cf. CoHEN 2017: 224-227; Тимотијевић 2019: 186-187). Херметичка филозофија, као и сфера алхемије и окултног у XVII и XVIII веку, такође је прихватила мајмуна као амблем „универзалног уметника", филозофа и алхемичара који опонаша тајне процесе природе (JANSON 1976: 306-308). Пародијски потенцијали мајмуна као персонификације уметника у визуелним уметностима Западне Европе, поготово са убрзаним развојем портретног сликарства, повезивани су и са Vanitas концептима, али и, у сатиричном духу, академским уметничким доктринама презаузетим имитацијом античких узора (singe peintre) (JANSON 1976: 308-312).

До које мере и да ли је уопште познавање савремених западноевропских филозофско-антрополошких и амблематских преокупација мајмунима постојало код аутора цртежа у Грабовановој ерминији тешко је са сигурношћу тврдити. Исто се може констатовати и за друге специфичне елементе садржаја рукописа који су настали након што га је Јован Четиревић Грабован купио са већ исписаним текстом ерминије на грчком језику. Утврђивање порекла одређених сегмената, попут преписа алхемијских табела из књиге Конрада Ернстинга не мора нужно значити и доказ о директном преузимању, односно непосредном контакту Јована Четиревића или Николе Грабована са поменутим издањем, као ни о коришћењу или пуној рецепцији садржаја књига из којих су преписани текстови потицали. Уметници и занатлије средњег и раног новог века у Западној Европи своја су техничка знања чували и преносили путем збирки рецепата неретко комбинованих са алхемијским текстовима и инструкцијама, а трансмутацијске алхемијске праксе и различите процедуре у уметничким или 


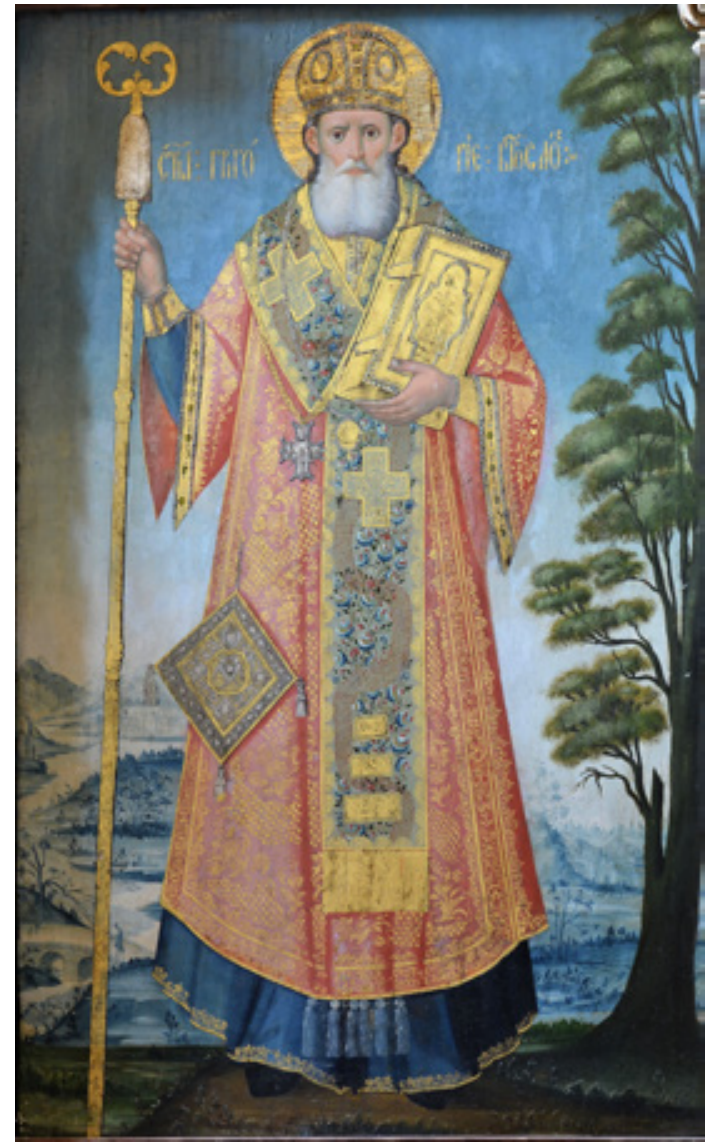

Сл. 11. Јован и Георгије Четиревић Грабован, Свеӣи Гриїорије Боїослов, престона икона на иконостасу цркве у Моловину, 1772. (фото: МСПЦ, Београд)

занатским радионицама често су биле међузависне. Многе сачуване рукописне компилације овог типа, поготово из германског културног круга, истовремено су, попут Грабовановог рукописа, садржавале текстове везане за различите области - ботанику, кулинарство, медицину, фармакологију, али и магијске поступке, све до савета о исхрани и практичних инструкција о кућној економији. У савременим истраживањима овакви компендијуми, комбиновани са текстовима утилитарне и информативне природе чији садржај није директно повезан са уметничким или религијским аспектима, сврстани су у посебан жанр тзв. Fachliteratur-e (NEVEN 2014: 22-27); корпус текстова који су у рукопису ерминије креирали Јован и Никола Грабован одговара оваквој жанровској дефиницији.

Претходна констатација намеће и питање утврђивања интелектуалних досега двојице Грабована и њихових могућности да стичу знања која нису била везана искључиво за сликарску праксу. Закључивања у том правцу могу се донекле поткрепити подацима о књигама за које се зна да су им заиста припадале, или су са њима долазили у непосредан контакт. За сада је познато да је Јован Четиревић Грабован био поседник, осим рукописне ерминије и примерка Вајглове илустроване Библије, још двају штампаних издања на грчком језику - једног старог синаксара из 16оо. и књиге $E \xi \dot{\alpha} \beta \iota \lambda \curlywedge \circ \dot{\eta}^{\prime}$

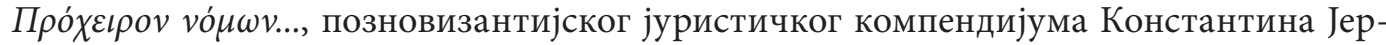
менопула, штампаног 1744. (Todorov 2000: 23, No. 1, 40 No. 93; cf. KučEKOvić 2020: 144). О Николи Грабовану као власнику књига нема директних података, али је он у рукопису очеве ерминије оставио запис о књигама које је 1812. „послао” свом брату Науму у Пешту (KUČEKOVIĆ 2020: 138). На списку од пет наслова наведени су један антоло-

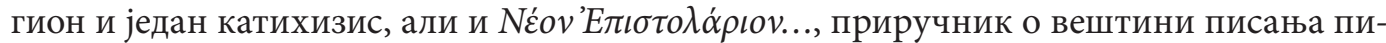

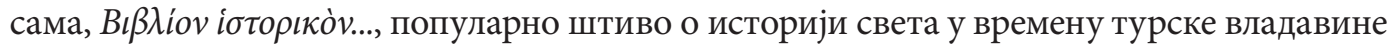

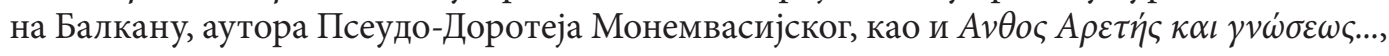


збирка просветитељских поука о поштеном и срећном животу човека обдареног врлинама попут друштвености, умерености, образовања, филантропије...; књига је у преводу на грчки штампана у Бечу први пут 1794. (ТАвAKI, SPHINI 1992: 267-268). ${ }^{19}$ Већина ових наслова може се и данас наћи међу сачуваним старим штампаним књигама на грчком језику некадашње библиотеке православне црквене општине у Пешти, која се чува у Њиређхази у Мађарској (Todorov 2000: 23-162; cf. NAGY 1999: 3-144). Примерак антологиона одштампаног у Лајпцигу 1761. вероватно је управо онај који је Никола Грабован послао из Осијека свом брату Науму у Пешту - у књизи је пронађен запис са именом Грабован (NAGY 1999: 126, кат. бp. G 613). ${ }^{20}$ Изгледа да су и књиге које су припадале занатлији и трговцу Анастасу Четирију Грабовану, Јовановом брату и Николином стрицу, који је такође живео у Осијеку и био угледни члан доњоградске православне црквене општине (Тодић 2010: 364-365), нашле свој пут до пештанске

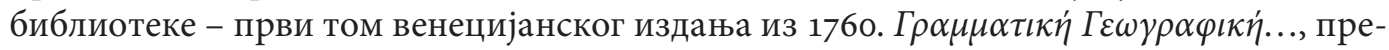
вод дидактичког трактата о географији шкотског аутора Патрика Гордона ${ }^{21}$, припадао је њему, а изгледа да је он био аутор и записа у једном венецијанском апостолу из 1762. и једном оштећеном примерку часловца (TODOROV 2000: 51, кат. бр. 159, 161, кат. бр. 876; cf. NAGY 1999: 109, кат. бр. G 522, 140, кат. бр. 696).

Наведене књиге су се, са свом различитошћу њихових садржаја, нашле у рукама Јована Четиревића Грабована и најближих чланова његове породице и свакако утицале на формирање њиховог заједничког интелектуалног оквира. Ипак, све су оне потицале из грчког културног и религијског круга, односно биле су штампане као преводи на грчки језик, што даје аргументе закључку да су писмени Грабовани из породице Јована Четиревића, у другој половини XVIII и почетком XIX века, европски свет у коме су се нашли, на интелектуалном плану, перципирали доминантно кроз ову врсту традиционалног ослањања на грчку ученост и језик. Њихова примарна професионална формирања остварена су такође у кругу традиционалног јужнобалканског трговачко-занатлијског система образовања, уколико изузмемо одлазак Јована Четиревића Грабована на усавршавање сликарске вештине „у Московију”, 1746-1750. (Тодит 2010: 361). Стицања додатних специфичних знања остајала су, како се чини, последица склопа индивидуалних способности, практичних потреба професије и

19 Никола Грабован је наслове књига исписао у скраћеном облику, ћирилицом, мешајући грчки и црквенословенски језик („Катихисисъ”, „Неонъ Епистоларионъ”, „Анөосъ Апестисъ” итд.), тако да није могуће утврдити о којим се тачно штампаним издањима ових књига радило.

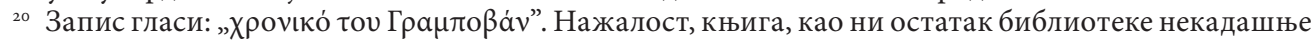
црквене општине у Пешти, није доступна за јавност, тако да, овом приликом, није било могуће проверити тачност ни контекст записа.

21 Трактат са изворним насловом Geography Anatomized: or a compleat Geographical Grammer први пут је објављен у Лондону 1693. као, по речима његовог аутора, основни приручник за познавање „модерне географије”. Књига је садржавала и преглед стања „европских плантажа Источне и Западне Индије” и, у мисионарском заносу написан, „разуман предлог” плана евангелизације колонија. Издања на енглеском језику, опремљена географским картама, појављивала су се све до 176о. (SITWELL 1993: $11,261-266)$. 
свакодневице, као и личне знатижеље. Рукописна ерминија Јована Четиревића Грабована, са разнородним записима и два занимљива цртежа, значајно, макар и посредно, употпуњује сазнања о идејним и културним утицајима којима су били изложени.

\section{ЛИТЕРАТУРА}

BeLICZA, Biserka. „Zdravstvo i zdravstvene prilike Slavonije u 18. stoljeću.” Peti znanstveni sabor Slavonije i Baranje: zbornik radova. Osijek: JAZU - Zavod za znanstveni rad, 1991, 293-304.

БЈЕЛАКОВИЋ, Исидора. „Називи болести у лекарушама са територије Војводине у 19. веку.” Прилози йроучавань језика (BJELAкоvić, Isidora. „Nazivi bolesti u lekarušama sa teritorije Vojvodine u 19. veku." Prilozi proučavanju jezika) 34 (2003): 5-36.

Williams, Linda. "Reflections on Modernity, Monkeys and Men: Edward Tyson and the Revelations of Enlightenment Science." PAN: Philosophy, Activism, Nature no. 5 (2008): 3-11.

ВукСАН, Бодин. Барокне теме срйской иконостиаса XVIII века. Нови Сад: Платонеум (VuкsAn, Bodin. Barokne teme srpskog ikonostasa XVIII veka. Novi Sad: Platoneum), 2016.

ГАВРИЛОВИЋ, Славко. „Исписи из старе архиве српске црквене општине у Осеку (XVIII-XIX век).” Зборник о Србима у Хрватиској (GAVRILOvić, Slavko. „Ispisi iz stare arhive srpske crkvene opštine u Oseku (XVIII-XIX vek).” Zbornik o Srbima u Hrvatskoj) 7 (2009): 453-460.

GLesinger, Lavoslav. Liječnici i čudotvorci. Zagreb: Zora, 1953.

Enenkel, Karl A. E. "Zur Konstituierung der Zoologie als Wissenschaft in dre Fruhen Neuzeit: Diskursanalyse zweier Großprojekte (Wotton, Gesner)." Early Modern Zoology: The Construction of Animals in Science, Literature and Visual Arts. Ed. by Karl A. E. Enenkel and Paul J. Smith, Intersections: Yearbook for Early Modern Studies 7/1 (2007): 15-74.

Ernsting, Arthur Conrad. Nucleus totius medicinae. Helmstadt, 1741.

Janson, Horst Waldemar. Apes and the Ape Lore in the Middle Ages and the Renaissance. NendelnLiechtenstein: Kraus reprint, 1976.

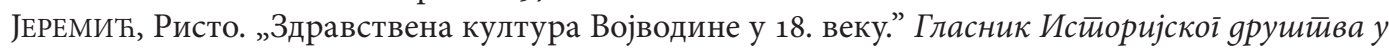
Новом Cagy (JеRемić, Risto. „Zdravstvena kultura Vojvodine u 18. veku.” Glasnik Istorijskog društva u Novom Sadu) 13 (1940): 268-276.

Jonstonus, Johannes. Historiae naturalis de Quadrupedibus, Amsterdami: Ioannem Iaocobi Fil. Schipper, 1657.

КучековИт, Александра. „Иконостас Јована Четиревића Грабована у Ораховици.” Зборник Нароgноі̄ музеја (Kuс̌екоvić, Aleksandra. „Ikonostas Jovana Četirevića Grabovana u Orahovici”. Zbornik Narodnog muzeja) XVII/2 (2004): 219-237.

KuČEković, Aleksandra. "Painters Jovan Četirević Grabovan and Grigorije Popović. Addenda to the Biographies of the Master and the Apprentice." Cаойūuerta 52 (2020): 138-152.

Levi D'Ancona, Mirella. The Garden of the Renaissance: Botanical Symbolism in Italian Painting. Firenze: Leo S. Olschi Editore, 1977.

Maguire, Henry. Nectar and Illusion: Nature in Byzantine Art and Literature. New York: Oxford University Press, 2012.

МАХОВ, Александр Евгеньевич. „Крокодиловы слезы, другие реалии и символы: эмблематика пересматривает бестиарную традицию." У: КулАгинА, О. Л. (ур.). Бестиарный коg культуры. Москва: Intrada M, 2015, 49-64. 
Medić, Mojo. „Četiri ljekaruše.” Zbornik za narodni život i običaje južnih Slavena knj. 14 (1909): 168-284.

Мирковић, Лазар. „Анђели и демони на капителима у цркви Св. Димитрија Маркова манастира код Скопља." У: Иконоїрафске ст̄⿲guje. Нови Сад: Матица српска (Mırкоvić, Lazar. „Anđeli i demoni na kapitelima u crkvi Sv. Dimitrija Markova manastira kod Skoplja.” U: Ikonografske studije. Novi Sad: Matica srpska), 1974, 253-261.

Moldenke, Harold N. Plants of the Bible. Waltham, Mass. (USA): Chronica Botanica Co, 1952.

МутАФов, Емануел. Европеизация на хартия. Съчинения за живописта на гръики език през пьрвата половина на XVIII в. София: Издателство АБА, 2001.

Moutafov Emmanuel. “Ioannes Tsetiris from Grabovo or Jovan Četirević Grabovan?” In: DrA-

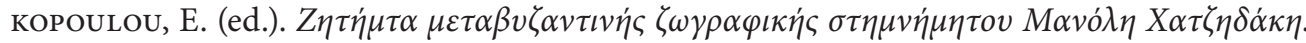

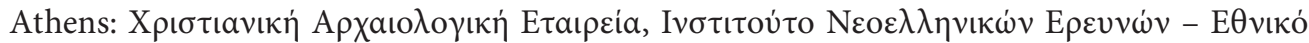

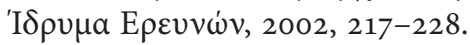

NAGY, Marta. “A nyíregyházi Szent György Magyar Ortodox Eegyházközség könyvállományának: katalógusa." Studia postbizantina hungarica: Posztbizánci közlemények IV. Debrecen: Kossuth Lajos Tudományegyetem, 1999.

Neven, Sylvie. "Transmission of Alchemical and Artistic Knowledge in German Mediaeval and Premodern Recipe Books.” In: Dupré, Sven (ed.). Laboratories of Art: Alchemy and Art Technology from Antiquity to the $18^{\text {th }}$ Century, Archimedes 37. New Studies in the History of Science and Technology. Heidelberg: Springer Verlag.

Niekerk, Carl. "Man and Orangutan in Eighteenth-Century Thinking: Retracing the Early History of Dutch and German Anthropology." Monatshefte für deutschen Unterricht, deutsche Sprache und Literatur Vol. 96, No. 4 (Winter, 2004): 477-502.

Prévost, Antoine-François. Histoire generale des voyages, ou Nouvelle collection de toutes les relations de voyages par mer et par terre. Tome sixième. La Haye: Pierre de Hondt, 1748.

Romano, Jaša. Jugoslovenska bibliografija lekaruša i narodnih medicinskih rukopisa. Beograd: Naučno društvo za istoriju zdravstvene kulture Jugoslavije, 1973.

РусевА, Ралица. „Зографски наръчник на Захари Зограф (НАИМ №11) - съедържание и приложение." Проблеми на изкуството 4 (2010): 9-14.

Salmon, George. The Universal Traveller: or a Compleat Description of the Several Nations of the World. Vol. II. London: Printed for Richard Baldwin, 1759.

SăNDUlescu-Verna, C. "Grigorie Frujinescu, începător al curentului realist în pictura românească." Biserica Ortodoxa Romana CIX, no. 4-6 (1992): 116-154.

Sebastiani, Silvia. "Challenging Boundaries: Apes and Savages in Elightenment." In: Hund, W. D., C. W. Mills, S. Sebastiani (eds.). "Simianization: Apes, Gender, Class and Race”, Racism Analysis, Series B: Yearbook, vol. 6 (2015-16): 105-138.

Sitwell, O. F. G. Four Centuries of Special Geography: An annotated guide to books that puport to describe all the countries in the world before 1888, with a critical introduction. Vancouver: UBC Press, 1993.

Spennemann, Dirk HR. "Matthäus Merian's crocodile in Japan. A biblio-forensic examination of the origins and longevity of an illustration of a Crocodylus niloticus in Jan Jonston's Historiae naturalis de quadrupetibus." Script \& Print: Bulletin of the Bibliographical Society of Australia \& New Zealand Vol. 43, No. 4 (2019): 201-239. 
Spennemann, Dirk HR. "Matthäus Merian's crocodile in the Historiae naturalis de quadrupetibus -Supplemental data-.” 2019a. <http://www.bsanz.org/wp-content/uploads/2020/12/ Spennemann-Merians-crocodile-supplementary-2.pdf.>

SтӧскеL, Heinrich Friedrich August. H.F.A. Stöckels, Hofschreiners zu Schleiz, practisches Handbuch für Künstler, Lackirliebhaber und Oehlfarben-Anstreicher. Nürnberg: Verlag der Stein'schen Buchhandlung, 1804.

Sтосzкоwsкi, Wiktor. "Portrait de l'Ancêtre en Singe: L’Hominisation sans Évolutionnisme dans la Pensée Naturaliste du XVIIIe Siêcle.” In: Corbey, R., B. Theunissen (eds.). Ape, Man, Apeman: Changing Views since 1600. Leiden: Leiden University 1995, 141-155.

TавакI, Anna, Alexandra Sphini. “Typologie des manuels d'éthique et de comportement en langue grecque vers la fin du 18e siècle. L'évolution du genre, reflet du processus de modernisation du Sud-Est Européen." Revue des etudes Sud-est Europeennes Tome XXX, No. 3-4 (1992): 253-268.

Тимотијевић, Мирослав. Срйско барокно сликарстиво. Нови Сад: Матица српска (ТлмотіJević, Miroslav. Srpsko barokno slikarstvo. Novi Sad: Matica srpska), 1993.

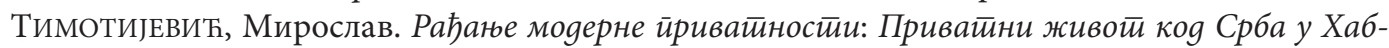
сбуршкој монархији оg краја 17. gо йочейка 19. века. Београд: Clio (Тімотіјеvić, Miroslav. Rađanje moderne privatnosti: privatni život kod Srba u Habsburškoj monarhiji od kraja 17. do početka 19. veka. Beograd: Clio), 2006.

Тимотијевит, Мирослав. Теоgор Крачун. Нови Сад: Галерија Марице српске - Покрајински завод за заштиту споменика културе (Tiмотіjević, Miroslav. Teodor Kračun. Novi Sad: Galerija Matice srpske - Pokrajinski zavod za zaštitu spomenika kulture), 2019.

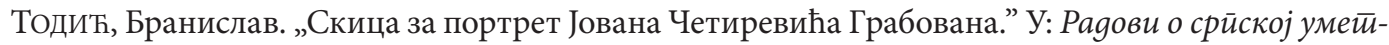

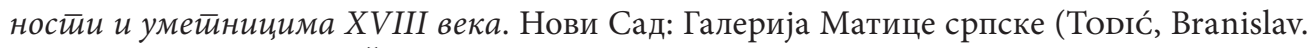
„Skica za portret Jovana Četirevića Grabovana.” U: Radovi o srpskoj umetnosti i umetnicima XVIII veka. Novi Sad. Galerija Matice srpske), 2010, 355-387.

Тодић, Бранислав. Срйски сликари og XIV go XVIII века. Књига I-II. Нови Сад: Платонеум (Todić, Branislav. Serbian Painters from $14^{\text {th }}$ to $18^{\text {th }}$ Century. Vols. 1-2. Novi Sad: Platoneum), 2013.

Тодић, Бранислав. „Грађа о иконостасу цркве Светог Георгија у Кобашу.” Љейойис СКД „Просвјет̄a” (ToDić, Branislav. „Građa o ikonostasu crkve Svetog Georgija u Kobašu.” Ljetopis SKD „Prosvjeta”) (2013a): 276-301.

Тодић-Ђурић, Марка. Фреске Маркової манасӣира. Београд: Балканолошки институт САНУ - Архиепископија охридска и Митрополија скопска (Томıс́-Đurić, Marka. Freske Markovog manastira. Beograd: Balkanološki institut SANU - Arhiepiskopija ohridska i Mitropolija skopska), 2019.

Todorov, Vurban. Catalogue of Greek Manuscripts and printed Books $\left(17^{\text {th }}-19^{\text {th }}\right.$ c.). The Collection in Nyiregyhaza Hungary: Contribution to the History of the Greek Diaspora. Athens: Centre for Neohellenic Research, 1999.

Tulp, Nicolaes. Nicolaii Tvlpi Amstelredamensis Observationem medicarvm libri tres. Amstelredami: Lvdovicvm Elzevirivm, 1641.

Tyson, Edward. Orang-outang, Sive Homo Sylvestris: or, The anatomy of a Pygmie Compared with that of a Monkey, an Ape, and a Man. To which is added, A Philological Essay Concerning the Pygmies, the Cynocephali, the Satyrs, and Sphinges of the Ancients. London: Printed for T. Bennett and D. Brown, et al. 1699. 
FIRINGER, Kamilo. „Osječke ljekarnice u drugom deceniju 19. stoljeća: borba za otvorenje prve ljekarnice u Gornjem gradu." Farmaceutski glasnik god. IX, br. 5 (1953): 240-248.

HaArbeck, Paul. Arthur Conrad Ernsting: Ein Aphotheker und Arzt des Barock. Eutin (Holstein): Internationale Gesellschaft für Geschichte der Pharmazie, 1953.

Habrich, Christa. "Characteristic Features of Eighteen-Century Therapeutics in Germany." Clio Medica 22 (1991): 39-50.

Ciobanu, Constantin I. “Trois cahiers de modèles des peintres roumains du XVIIIe siècle.” Y: Moиивви, Моgели, Погодовителни рисунки. Изкуствоведски чтениа 2019 (Art Readings 2019). Sofia: Institute of Art Studies, 2019, 91-118.

Cohen, Simona. Animals as Disguised Symbols in Renaissance Art. Leiden-Boston: Brill, 2008.

Cohen, Simona. "Ars simia naturae. The Animal as Mediator and Alter Ego of the Artist in the Renaissance." Explorations in Renaissance Culture 43 (2017): 202-231.

Curley, Michael J. Physiologus: A Medieval Book of Nature Lore. Chicago \& London: University of Chicago Press, 2009.

\section{Aleksandra P. Kučeković \\ ERMINEIA BY THE PAINTER JOVAN ČETIREVIĆ GRABOVAN - RECORDS AND DRAWINGS}

\section{Summary}

The handwritten ermineia of the painter Jovan Četirević Grabovan, kept in the library of the Orthodox Church in Nyíregyháza, Hungary, contains, in addition to the main text, other records, texts, and drawings that father and son, Jovan and Nikola Grabovan, entered until the middle of the fourth decade of the $19^{\text {th }}$ century. The paper analyzes the origin and content of this heterogeneous group of texts, which provides insight into the range of their professional, intellectual, and also everyday practical interests and needs. The records and drawings in the manuscript also testify to the divergent influences and sources of knowledge to which they were exposed, primarily in terms of contact with the contents of Western European publications in medicine, pharmacy, chemistry/ alchemy, and perhaps even geography and zoology. Special attention is paid to the identification of the sources from which the transcribed texts originate, with most of them being determined quite precisely. The variety of texts that appear on the pages of the manuscript makes it a kind of multifunctional family thing in which the two authors noted important dates, practical knowledge that marked work and everyday life, as well as very special excursions into the world of exotic animals and alchemy. Most of the texts remained related to the painting profession, while two drawings of animals were specially analyzed in the contexts of their symbolic and iconological potentials. The content of the manuscript raises the question of determining the educational and intellectual achievements of Jovan Četirević and Nikola Grabovan who were primarily grounded in the South Balkan tradition and modern Greek scholarship, open at the same time to different Western European influences.

Keywords: Jovan Četirević Grabovan, Nikola Grabovan, post-Byzantine painting manuals (ermineia), records of Serbian painters, drawings by Serbian painters of the $18^{\text {th }}$ and $19^{\text {th }}$ centuries, animals in art, monkey in art. 